\title{
Particle - a Small Lexical Unit or an Endless Scientific Project?
}

\author{
E.A. Markova \\ Peoples' Friendship University of Russia (RUDN University) \\ 6, Miklukho-Maklaya str., Moscow, 117198, Russian Federation
}

The article aims to explain the popularity of studying particles in present-day Russian and foreign linguistics. A comparative analysis of various approaches to the study of particles proved their importance in language structure, and the linguistic concept created by the Russian scientist and systemologist G.P. Melnikov allowed to define the internal determinant of the language using functional words, namely, particles, as one of the subsystem elements responsible for the stability of the supersystem and the whole system work. Due to different external and internal factors influencing on the development of the Russian and English languages, the formation of particles as a wordclass is different. Russian particles are recognized as a functional class because it is impossible to express the communicative content of the utterance, the attitude to the content without their participation, which determines the event determinant and the dynamic deployment of perception, whether language units acting as particles in the English language have polystatuting, depending on the semantic and syntactic environment, which characterises the occasional determinant and static, descriptive perception.

Key words: theory of system-typological linguistic determinants, event determinant, occasional determinant, inflecting languages, root-isolating (amorphous) languages, polysemy

\section{Introduction}

The study of Russian and English "particles" has been uninterrupted for more than two centuries and has involved both Russian and foreign researchers because particles are capable of conveying numerous semantic and emotional nuances though being such small units in size. Therefore, researches in linguistics are filled with new unexplored aspects, allowing to penetrate deeper into the nature of these special words, indicating their non-random appearance and development in the language system.

The findings of the Russian linguist T.M. Nikolayeva that particles carry the entire maximum of the communicative stratum in the utterance [1] continue the conclusion of the famous British teacher and philosopher John Locke that particles show the attitude of the mind to one's own thoughts and those who wish to indicate the correct use of particles, their meaning and the importance should penetrate into one's thoughts and carefully observe the various positions of the mind during a conversation [2].

Considering Russian and English particles from different sides, modern researchers note their special position in the language, connecting them with the peculiarities of the language system. However, linguists do not refer to the linguistic concept of the Russian scientist G.P. Melnikov, regarded as the creator of system linguistics whose work should expand the research field of specific linguistics (English and Russian) in the study of 
functional words, namely, particles, as special indicators in the identity of the language communicative aspect.

Particles include such word-classes that add additional nuances to the meanings of other words, groups of words, sentences, or serve to express various grammatical, and, consequently, logical and expressive relations. The concept "particle" contains four semantic complexes that are interconnected and their study helps to understand the development of different levels in the structure of languages and the diffuse transitions of language units from one level to another: the first complex regards the opposition of the functional words class to the notional words class; the second complex considers particles as immutable components that join autonomous words and form certain grammatical forms. These forms, in turn, paradigmatically and categorically relate to forms that can be formed without particles; the third complex applies to studying ancient languages, where particles are considered as connectors or conjunctions, which (as V. Dresler does in his work on the Indo-European syntax) later turn into inflectional morphemes and pass into another group; the fourth complex refers to the ability of a word to convey various communicative characteristics to the message [3].

In modern language, it is not always possible to distinguish a conjunction from a particle, a particle from an interjection, a particle from a pronoun, particles-conjunctions, particles-adverbs, particles-introductory words, etc. And if in Russian particles have two terms - particles and partikulas, in English particles are understood as so-called "P-forms", which include both prepositions and particles, combinations of verbs and particles, the meanings of which can vary, depending on the interaction with other language units in the same utterance or in various communicative contexts.

Despite the considerable experience gained in classical theoretical linguistics in the study of particles, functioning in many languages, researchers are unanimous in their opinion that particles are not nominative units of language.

We believe that the linguistic concept of the Russian scientist and systemologist G.P. Melnikov could expand the specific linguistics research field in the study of functional words - particles as indicators of the identity in the language communicative aspect, especially in the era of global Englization and the intensive variability of Englishes. G.P. Melnikov noted that when examining one component of the system, researchers obtain data on other components of the system, giving representatives of different linguistic schools the opportunity to get mutually agreed and mutually complementary data on the language [4].

Materials and methods. The comparative analysis of particle researches in the Russian language based on the works of such Russian scientists as Vinogradov, Muminov, Alpatov, Nikolaeva, Starodumova, Minchenkov et al., and P-forms, particle constructions based on the works of western researchers such as Locke, Bolinger, Lindner, Lakoff, O'Dowd, Debra, Capelle and others allowed to identify the causes of different approaches in the study of particles in compared Indo-European languages. The application of some Melnikov's systemic linguistics provisions made it possible to determine the particles as significant elements in the formation of the internal form of the language, and the continuous sampling method, on the V. Nabokov's novel "The Luzhin Defence" in Russian and English, confirmed the provisions on various types of language internal determinants. 
Results have indicated that:

- G.P. Melnikov's linguistic concept falls outside the scope of language research;

- the study of the language internal determinant, namely its communicative aspect, is possible through one of its components - particles, which are special linguistic units for the transmission of referential content and attitude to this content;

- different approaches to the study of particles, their formation and number as a class of functional words in the Russian language and P-forms in the English language are due to the typological differences between the two languages.

\section{Discussion}

From the 18th century, Russian particles have been constantly interpreted and described as a special layer in the lexical composition of the Russian language, first as a part of adverbs and conjunctions, then academic community coined a special term - "particle", later particles received the status of independent speech units and a word-class performing an auxiliary function in speech. Further, as a purely syntactic category related to functional words, particles became distinguishable in their functions and were divided into categories. Such continuity allowed to formulate a provision on the interdependence of semantics and functional properties of particles. At the present stage of Russian linguistics, particles as a special layer in the Russian language vocabulary - "our entire communicative foundation" [3] are recognized as a functional class due to the sustainability of their use in expressing the communicative content of any utterance.

Hence, Starodumova [5] emphasizes that the semantics of particles is manifested in their functions and includes pragmatic components and elements of objective information, making them the most important means in organizing a coherent text and "auxiliary" elements in making syntactic constructions.

Russian scientists Nikolaeva [1] and Muminov [6] find that the lack of denotative meaning determines the interconnection between their semantics and functional properties.

In foreign linguistics, interest in particles also has not waned since the 17th century: this is Walker's Treatise on English Particles [7] where he notes the great diversity of their use, but their ignorant explanation; this is also Lock's work [2], in which he points out that particles are the relation between the mind and the thoughts and that their correct use requires a creative approach in conversation. In the $70 \mathrm{~s}$, the theory of presupposition was actively developed.

In the $80 \mathrm{~s}$, the phenomenon of focusing and rematization shifted the focus of linguists to the study of particles, along with adverbs, modal words and other focusing adverbs. The works of Bolinger, Brugman, Langacker, Lakoff demonstrate that so-called $\mathrm{P}$-phenomena and $\mathrm{P}$-forms are classified according to the propositional context both as a particle and as a preposition. The scientists make attempts to classify this phenomenon at the syntactic level.

O’Dowd [8] in her monograph "Prepositions and Particles in English. A discoursefunctional account» insists on the discursive-functional approach to the "P-phenomena", which should allow to distinguish prepositions from particles. O'Dowd writes that the verb-particle and verb-preposition constructions have synonyms: to put out - to 
extinguish; to look into - to investigate; to climb up - to ascend. And in each case, discourse-pragmatic motivation will govern the semantics of words and sentences. She suggests considering $\mathrm{P}$-forms as pragmatic, discourse-oriented elements, rather than syntactic and semantic elements. It is the orientational function that determines the grammatical functions of prepositions, particles, or other lexical categories, which leads them to semantic expansion in various meanings. More importantly is that O'Dowd concludes that syntactical and grammatical violations can be caused by the dynamics of language change.

After reviewing some theories of English linguistics, B.Cappelle [9] notes that the verb-particle construction attracted the creators of theories primarily because of the particle mobility in transitive models. For Chomsky, for example, all particles formed the base for the verb and were to the left of the object closest to the verb; Ross did not consider some particles at all, but those that he considered were included in the basis of the word; for Jackendoff, all particles were the basis for object-idiomatic expressions, a central theme for Dehé and Gries was word order in active transitive sentences.

B. Cappelle points two main reasons for such popularity of studying particles in English linguistics and here we agree with him. The first reason is that English is the modern scientific lingua franca and the second reason is the fact that English is the most studied language in the world. As a result, its structural description constitutes the basis of modern linguistic theory. The multiplicity of verb-particle combinations in the English language has found its place in the general theories of grammar. The grammar models that work for English have the same dominant status as in the recent past, although at present the Greek-Latin descriptive formats are rejected, most modern terminology is still based on the Greek-Latin model [9].

Another related reason is that many of the leading linguists speak Germanic languages, and therefore, regardless of whether their native language is English, German, Dutch or Scandinavian, they are familiar with particles or their close analogues, for example, separable verb prefixes that can be found in their native language. In fact, particles or "particoids" (partikuls) are not such rare phenomena in all world languages. Moreover, a limited number of patterns allows to create an unlimited number of possible combinations, what indicates the analytical form of the language.

According to Talmi [10] and Slobin [11], such elements can be found in most IndoEuropean languages (except for the Romance languages), in Latin, in Finno-Ugric languages, such as Finnish, Estonian, and Hungarian, in Chinese and in the TibetoBurmese language Lahu, in Indian languages such as Ojibwa, Kaddo and Atsugevi, as well as in the Australian aboriginal language of Warlpiri. In these languages, "satellites" to the verb, accountable for expressing direction, can appear in the form of verb prefixes or so-called "co-verbs", in serial verbal constructions, initial morphograms forming the stem, nouns with an incorporated object, polysynthetic affixes adjacent to the root verb, suffixes, enclicics, etc.

The third reason is that, regardless their simplicity, verb-particle combinations are among the most complex linguistic objects. As Bacchielli notes, even today the linguistic community, characterized by different theoretical doctrines and methodological approaches, could not present any unified theory on phrasal verbs. There is still no answer to the question whether "verb-particle combinations" are words or phrases, whether 
particles are morphological components of grammar or items of combinatorial syntax rules. Being such familiar structures and, nevertheless, not easy to description, verbparticle combinations are an excellent experimental platform for testing how well a welldefined theory explains some of the most important problems in grammar, such as the structure of words and phrases, idiomatic nature compared with compositionality, categorization, word order changes, etc.

The works of Russian and foreign researchers prove that creativity is an essential property of any language, although there is a gradient between acceptable and completely unacceptable grammatical structures of the sentence. The actual utterance unacceptability depends on how seriously the preferred post-verbal components ordering is broken. But the general principle of discourse functioning usually presents familiar information at an early stage in a sentence. In his lexico-grammatical conception of language B.Cappelle points that the generating ability of abstract high-level structures is not ontologically different from the creative use of low-level elements of constructive idioms. Although, as the scientist adds, there would be more "end assets", but still less as compared to the countless possibilities that they have.

Similarly, Chomsky, referring to the predecessors of his generative theory, notes that the emphasis on the "creative aspect of using language" (and the subsequent need to posit "innate ideas") was already presented in the works of some rationalists, such as René Descartes and some romantics, such as the linguist and philosopher Wilhelm von Humboldt, who described language as a system that, if we wanted to explain this creativity, such system should "endlessly use finite means" [9].

The comparative analysis of different approaches to understanding and describing particles suggests that the theory of the system-typological determinant created by G.P. Melnikov, which is based on understanding the language as a self-adjusting dynamic system, remains outside of the researches, and the internal determinant should be considered as the most important property of any language structure and type. The inner determinant is realized in the communicative perspective, in the peculiarities of the semantic scheme of typical utterances.

The study of particles as a non-grammatical, but functional class under pragmatics, the analysis of their functions (the function of expressing attitude both rational and emotional) in a particular discourse brings us to the idea that the attitude that particles show can be either rational (occasional determinant of the English language) or emotional (event determinant of the Russian language).

As Makoveeva [12] points out, the restructuring in the English language system towards the isolating type in the Late Middle English period affected the difficulty in determining particles as a class. The collapse of the inflecting system led to close relationship between morphology and syntax, which increased the constructive and identifying significance in the word order, actualization for the constructive elements in the sentence, and therefore they were rarely used for particles. This, in turn, reduced boundaries of this word-class.

This means that norms of the English language, tending towards the isolating type languages, predetermined the prospects for the development of particles as a class and caused their limited number. To realize new communication goals, already established in the language resources were modified through transposition and, thus, explaining particles formation from another part-of-speech words and their specificity as units that 
perform specific communicative functions in speech. Particles in the English language serve as specifiers of the communicative segmentation in the sentence, indicated by logical stress, word order, context, and intonation. And this means that the typological differences in languages cause differences in the methods for communicative classification of concrete and abstract meanings, segmentation of senses into meanings to transmit the content. The expression of the ultimate meaning by means of different languages depends on their position. In one language, the senses of words are among the closest ones and carried out by the means of a single-word nomination, in another language a co-nomination is required, i.e. the usual meanings of more than one words [4].

The analysis of particle studies shows their significant role in discourse and confirms G.P. Melnikov's thesis on the uniformity of ways of thinking and the content, and communicative causation of the internal determinant of a language, which is manifested in the peculiarities of the semantic scheme in typical utterances, where the distinction between functional and notional words in this scheme contributes deeper understanding of the typological features of languages. The differences in the inner determinants of the two inflecting languages - English and Russian - relate to their dynamic characteristics and descriptiveness. So, according to G.P. Melnikov, the Russian language is distinguished by an event-based determinant and dynamic deployment of perception but English, on the contrary, is characterized as static and descriptive, which is largely due to the historical decline of grammatical forms and fixed word order. The multifunctional use of resources in the English language system is unique to occasional internal determinant, creative in relation to the use of existing characters including particles taking into account the context, the situation of communication, the individual characteristics of the recipient.

In confirmation of this, A. Weirzhbitska [13] in her studies, based on the comparative analysis of the syntactic constructions in the Russian and English languages, concludes that the syntactic typology of languages indicates two different approaches to life, which play different roles in different languages: human life can be considered from the viewpoint of "what I am doing", i.e. to adhere to an active orientation, and from the the view-point of "what happens to me", following a patient orientation. "Therefore, the English and Russian languages should have different types of sentences as dominant. At the same time, elements such as p-phenomena will be aimed at various mode background assumptions. "The English language usually represents all life events happen to us, as if we completely control them, as if all our expectations and hopes are under our control; even restrictions and forced actions are represented in English from this point of view $<\ldots>$ For Russian, there are much more typical constructions in which all restrictions and compulsions are given in the patient mode" [13].

The analysis of the Russian and English texts "The Luzhin Defense" convinced us that the same dictum core (the propositional basis of the utterance) V. Nabokov placed into different, often non-coinciding modes. In English, the sentence was focused on rationality, a causal component, in Russian the particles reinforced the meaning of "uncontrollable events" (what Wezhbitska calls non-agentiality, providentialism, fatalism, spontaneity) [13].

«Я его расспрашивала о школе, - говорила она, не глядя на мужа, - он не хотел отвечать, - а потом, вот... как бешеный...» [14]. 
For the Russian-language text situational, rapid results are important and the final result semes are used. A particle «вот» appears here as an event indicator that unfolded "by itself", "collapsed" on participants - we can see here additional semantic nuances of passivity ("Event X happened by itself", "befell”), (expressiveness), but in the English text -

'I was asking him about school," she would say, not looking at her husband. 'He didn't want to answer and then - like a madman...' [15] -

there is no equivalent for this particle. An adverb with cause-and-effect semantics takes the place, indicating the sequence of events: "Event X occurred, after which Y reacted to it". As we can see, the same dictum "core" exists in different modalities, though the " 0 " equivalent is used in the English version. In the Russian-language text, the tendency towards irrationality and fatalism is preserved and strengthened; but in the English text, on the contrary, rationality is emphasized, the cause-and-effect propositional level is stressed.

" 0 " equivalent or the omission in the sentence can also be used for the speech compression here and, as we believe, it is replaced by stress, segmentation, position, phonology.

Night descends on the train [15]. И вот, ночь в вагоне [14].

Perhaps, taking into account the cognitive features of the addressee and creating a foreign language modality, V. Nabokov used the verb to descend (poetic) in the English version instead of roll in / come down - to advance, to approach (about twilight, nights) to transmit Russian conjunction and particle «И вот», which confirms the specifics of the English language system.

In the Russian-language text "The Luzhin Defense" V. Nabokov used a bundle of particles whereas in the English version the author chose " 0 " equivalent for the translation or focusing on the one that could be adequately perceived by the readers of his English novel.

«Блещи, пока блещется», - сказал он, после того незабвенного турнира в Лондоне, первого после войны, когда двадцатилетний русский игрок оказался победителем. - «Пока блещется, - лукаво повторил Валентинов, - а то ведь скоро конец вундеркиндству» [14].
"Shine while you can", he had said after that unforgettable tournament in London, the first after the war, when the twenty-yearold Russian player came out the victor. "While you can", repeated Valentinov slyly, "because you won't be a boy prodigy much longer" [15].

A bundle of particles « $а$ то ведb» testifies to the uncontrollability of events, whereas in English the negative modal verb "won' $t$ " indicates rationality and a cause-and-effect link.

Ведь это же не человек [14]. Certainly not a real person [15].

To express evidence and irritation, Nabokov used two particles «ведb» and «же» in Russian, whereas in English he chose one particle with the emphasis on it "not".

«...а ведь старик-то, господа, в свое время проклял дочь...» [14] "...and yet, gentlemen, the old man had cursed his daughter in his time...” [15] 
In the Russian language text, Nabokov used three particles «a», «ведb», «-mo» to actualize and enhance the emotionality of the utterance, but in English he chose "and yet" the conjunction and the particle to enhance the meaning; definite article "the" to actualize and identify the object; intensify the sense.

These examples confirm the differences in the internal determinants of languages: Russian with its event determinant and English with its occasional determinant. In both cases, regardless of the number and form of language units, the sense remains the same.

In his research B. Cappelle also assigns a leading position to particles in the endless number of phrasal verbs. Two words combinations - go in, come out, open up (enter, exit, open) are considered complex or phrasal verbs - i.e. verbs with an added non-verbal element, which grammatists call a "particle". He proposes to consider particles not as an attachment to a verb, but as a primary element in a verb-particle combination, because in endless verb-particle combinations as a finite set of structures with a predetermined particle and an open position for the verbal element, which can be a noun, an adjective outside the combination, a verb-particle combination is not so much a verb that forms a phrase with a particle, but a construction of a particle that forms a phrase with a (possibly derived) verb. The particle does not even need a verb, it cannot be regarded as an element depending on the presence of a verb: Pens down! Away with this rubbish! A particle can head its own phrase: go in (that is the way a native speaker would sound it) in a certain context means go right back in towards the bar (as it would sound in the Russian language) the particle "in" appears as a phrase core, and the particle "back" (обратно), the adverb "right" (прямо), the preposition and the complement "towards the bar" - as specifiers. (The preference in choosing lexical units in this case depends on the type of language: the phrase "go in" will characterise inflecting and analytical English, but the phrase "go right back in towards the bar" will characterise an inflecting and synthetic Russian).

Bert Cappelle's study on the leading position of particles in phrasal verbs constructions confirms the conclusions made by Minchenkov [16], Makoveeva [12] and other Russian scientists on the communicative and pragmatic properties of particles and testifies to the creative occasional determinant of analytical English, when every time you have to make a motivated choice between a particle, a preposition or other P-forms elements of the whole system.

We believe that particles in the Russian language and English particles ( $\mathrm{P}$-forms; P-words; P-phenomena) are special language units which represent a stable sublevel of the lingual system that participates in the formation of the human linguistic consciousness. The pneumatic sphere, which covers all levels of the language and the language system with its referential content entirely contributes to the high stability of the entire system, thus reaffirming the validity of the system-typological theory of the language determinant by G.P. Melnikov for studying the communicative aspect of different languages through functional words.

\section{Conclusion}

The comparative analysis of different approaches and stages in the study of Russian and English particles as compulsory classes of lexemes belonging to any language system 
has led to the conclusion that the difference of scientific traditions in the study of particles depends on the historical experience of language development, the formation of culture in a specific linguistic community, which, in their turn, affect the differences in the specific system of these languages.

And if, according to Alpatov [17], the distinction of words freely moving within a sentence and words with a rigid position would mean a lot to the Russian language, then in English, where almost any word has a strictly fixed position, the distinction between notional and functional words is less strong. The popular names of particles such as P-phenomena, P-words, P-forms, in the works of O'Dowd, Debra, Cappelle prove Alpatov's confirmation and that the specific pragmatic meaning which particle receives in the sentence, phrase, text, depends on some factors that can act individually or all together. They are the assignment of a particle to a single word or the entire utterance; the nearest linguistic environment of the particle, as well as its ability to perform a certain function individually or only in combination with other words; the syntactic structure in which the particle is used; logical relation between the utterance with the particle and other utterances; additional implicit values presented in the particle.

The phenomenon of particles lies in the peculiar communicative aspect of the language system, in their dynamic, mobile, sometimes elusive state which should be viewed as a scientific project without completion due to the constant development of the language and its inexhaustible possibilities caused by the dynamic development of the reality, surrounding a man.

\section{References}

1. Nikolaeva, T.M. 1985. Funkcii chastic v vyskazyvanii (na materiale slavyanskih yazykov) [Particle Functions in the Utterance (on the material of the Slavic languages)]. Moscow: Nauka. Print. (In Russ.)

2. Lokk, Dzh. 2004. "Opyt o chelovecheskom razume" [The Experience of the Human Mind] in Izbrannye filosofskie proizvedeniya v dvuh tomah. Moscow. Print. (In Russ.)

3. Nikolaeva, T.M. 2008. Neparadigmaticheskaya lingvistika (Istoriya bluzhdayushchih chastic) [Non-paradigmatic Linguistics (History of Wandering Particles)]. Moscow: Yazyki slavyanskih kul'tur. Print. (In Russ.)

4. Mel'nikov, G.P. 2003. Sistemnaya tipologiya yazykov [System Typology of Languages]. Moscow: Nauka. Print. (In Russ.)

5. Starodumova, E.A. 2002. Chasticy russkogo yazyka (razno-aspektnoe opisanie) [Particles of the Russian language (Multi-aspect Description)]. Vladivostok: izd-vo Dal'nevostochnogo un-ta. Print. (In Russ.)

6. Muminov, V.I. 2011. Stilisticheskie funkcii chastic v romane F.M. Dostoevskogo "Idiot" [The Stylistic Functions of Particles in the Novel by F.M. Dostoevsky's "The Idiot”]. Yuzhno-Sahalinsk, 2011. Print. (In Russ.)

7. Walker, W. 1970. A Treatise of English Particles. Menston, The Scholar Press.

8. O’Dowd, E.M. 1998. Prepositions and Particles, a Discourse-functional Account. New York: Oxford University Press.

9. Cappelle, B. 2005. Particle Patterns in English. A Comprehensive Coverage, Katholieke Universiteit Leuven Faculteit Letteren Departement Lingui stiek.

10. Talmy, L. 1991. "Path to Realization: a Typology of Event Conflation". In: Laurel A. Sutton, Christopher Johnson and Ruth Shields (eds.), Proceedings of the Seventeenth Annual Meeting of the Berkeley Linguistics Society. Berkeley: Berkeley Linguistics Society: 480-519.

11. Slobin, D.I. 1996. "Two ways to travel: Verbs of Motion in English and Spanish". In: Grammatical Constructions: Their Form and Meaning. Oxford: Oxford University Press: 195-219. 
12. Makoveeva, S.E. 2001. “Chasticy v sovremennom anglijskom yazyke: Genezis i funkcional'nyj aspect” [Particles in Modern English: Genesis and Functional Aspect]. Dis. Thesis. Arhangel'sk. Print. (In Russ.)

13. Weirzhbitska, A. 2011. Language Universals and Basic Concepts. Moscow: Languages of Slavic culture. Print. (In Russ.)

14. Nabokov, V. 2007. Zashchita Luzhina: Roman [The Luzhin Defense]. St. Petersburg: Izdatel'skij Dom «Azbuka-klassika». Print. (In Russ.)

15. Nabokov, V. 1990. The Luzhin Defence. Vintage International. Vintage Books. A Division of Random House, Inc., New York.

16. Minchenkov, A.G. 1999. "Diskursnaya chastica: analiz perevodcheskih sootvetstvij v anglijskom i russkom yazykah" [Discourse Particle: Analysis of Translation Correspondences in English and Russian languages]. Print. (In Russ.)

17. Alpatov, V.M. 2010. "Dvadcat' let spustya" [Twenty Years Later] in Yazyk i obshchestvo v sovremennoj Rossii i drugih stranah: Proceedings (Moscow, June 21-24, 2010). Print. (In Russ.)

(C) Markova E.A., 2018

This work is licensed under a Creative Commons Attribution 4.0 International License

\title{
Article history:
}

Received: 12.09 .2018

Accepted: 29.12.2018

Moderator: V.P. Sinyachkin

Conflict of interests: none

\section{For citation:}

Markova, E.A. 2019. "Particle - a Small Lexical Unit or an Endless Scientific Project?". Polylinguality and Transcultural Practices, 16 (1), 84-94. DOI 10.22363/2618-897X-2019-16-184-94

\section{Bio Note:}

Elena A. Markova is a Candidate of Philology, Senior lecturer at Foreign languages department, Faculty of Humanities and Social Sciencies, Peoples' Friendship University of Russia. E-mail: markova_ea@pfur.ru (abellen@yandex.ru)

\section{Частица - маленькая лексическая единица или бесконечный научный проект?}

\author{
Е.А. Маркова \\ Российский университет дружбы народов \\ Российская Федерация, 117198, Москва, ул. Миклухо-Маклая, д. 6
}

Целью данной статьи является объяснение возрастающего интереса к исследованию частиц в современном отечественном и зарубежном языкознании. Сопоставительный анализ различных подходов к изучению данной проблематики показал их значимость в структуре языка, а лингвистическая концепция российского ученого-системолога Г.П. Мельникова позволила 
определить внутреннюю детерминанту языка посредством служебных слов, а именно частиц как одного из элементов подсистемы, отвечающих за устойчивость надсистемы и работу всей системы в целом. В силу разных внешних и внутренних факторов развития русского и английского языков становление класса частиц различно.

Русские частицы признаны функциональным классом в силу невозможности выражения коммуникативного содержания высказывания, отношения к содержанию без их участия, что определяет событийную детерминанту и динамическое развертывание восприятия, а языковые единицы, выступающие как частицы английского языка, имеют полистатутность в зависимости от семантического и синтаксического окружения, что характерно для окказиональной детерминанты и статичного, описательного восприятия.

Ключевые слова: теория системно-типологической языковой детерминанты, событийная детерминанта, окказиональная детерминанта, флективные языки, корнеизолирующие языки, полисемия

\section{История статьи:}

Дата поступления в редакцию: 12.09.2018

Дата принятия к печати: 09.08.2018

Модератор: В.П. Синячкин

Конфликт интересов: отсутствует

\section{Для цитирования:}

Маркова E.A. Частица - маленькая лексическая единица или бесконечный научный проект? 2019. Т. 16. № 1. С. 84-94. DOI 10.22363/2618-897X-2019-16-1-84-94

\section{Сведения об авторе:}

Маркова Елена Андреевна - кандидат филологических наук, старший преподаватель кафедры иностранных языков факультета гуманитарных и социальных наук Российского университета дружбы народов. E-mail: markova_ea@pfur.ru (abellen@yandex.ru) 